\title{
Ring-enhancing pontine lesion in a young boy
}

\author{
Brandon C Gabel, ${ }_{1}^{1}$ Michael L Levy, ${ }_{1}^{1}$ Janet Yoon, ${ }^{2}$ John Ross Crawford ${ }^{3}$
}

1 Department of Neurosurgery, University of California San Diego, San Diego, California, USA

${ }^{2}$ Department of Pediatrics, University of California San Diego, San Diego, California, USA

${ }^{3}$ Department of Neurosciences and Pediatrics, University of California San Diego, San Diego, California, USA

\section{Correspondence to} Dr John Ross Crawford, jrcrawford@ucsd.edu
To cite: Gabel BC, Levy ML, Yoon J, et al. BMJ Case Rep Published online: [please include Day Month Year] doi:10.1136/bcr-2013201335

\section{DESCRIPTION}

A 10-year-old boy presented with a 1-month history of headache, vomiting and progressive weakness. On neurological examination the patient had left hemiparesis, dysconjugate gaze with nystagmus and right-sided sixth nerve palsy. Review of systems was negative for fevers or prior illness. A T1 contrast-enhanced MRI revealed a ring-enhancing lesion situated in the pons with surrounding vasogenic oedema (figure 1). Owing to the unusual MRI features and extensive differential diagnosis of ringenhancing lesions, the patient was taken to the operating room for a biopsy where pathology was consistent with a diagnosis of high-grade glioma. Postoperatively the patient tolerated the biopsy without complications and received conformal intensity modulated radiation therapy and concomitant oral temozolomide.

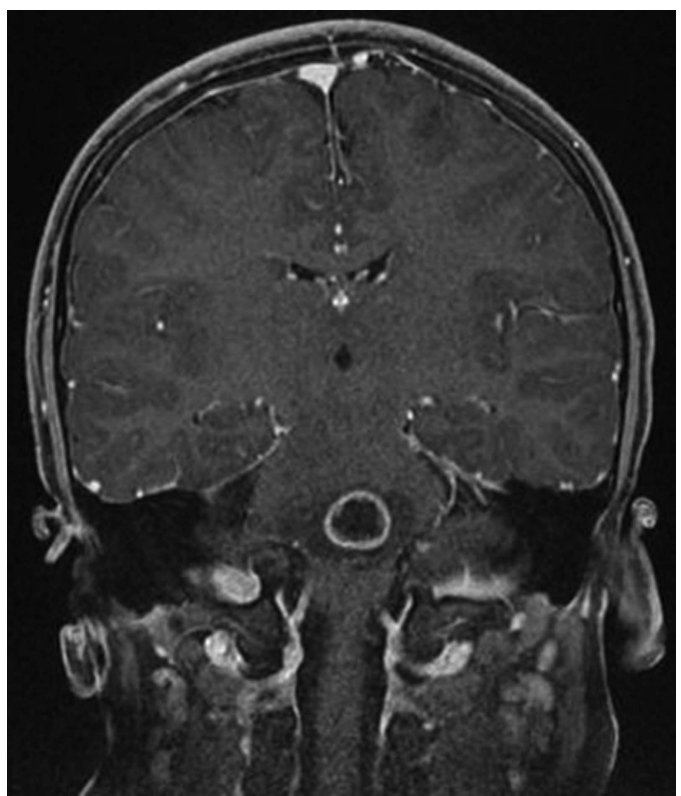

Figure 1 MRI features of pontine lesion. T1 postgadolinium sequences reveal a ring-enhancing pontine lesion with surrounding vasogenic oedema where pathology revealed a high-grade glioma.
Unfortunately, the boy died 8-months after the biopsy due to the progression of the disease. Brainstem gliomas in children can be broadly classified as focal or diffuse. High-grade brainstem tumours in children are most commonly diffuse intrinsic pontine gliomas and do not show focal enhancement. ${ }^{1}$ Contrast enhancing brain stem lesions that mimic tumours include infectious aetiologies such as toxoplasmosis, bacterial abscess, neurocysticercosis, sarcoidosis and tumefactive demyelinating disease. Our case highlights the unusual ring-enhancing characteristics of paediatric high-grade brainstem glioma and supports the current literature that brainstem biopsy can be performed safely with minimal morbidity in cases where a diagnosis is unclear. ${ }^{23}$

\section{Learning points}

- The differential diagnosis of ring-enhancing brainstem lesions includes neoplasm, demyelinating disease and infectious aetiologies.

- High-grade glioma should be considered in the differential diagnosis of ring-enhancing brainstem lesions.

- Biopsy of brainstem lesions is safe and may be helpful in guiding further treatment in cases with atypical neuroimaging features.

Competing interests None.

Patient consent Obtained.

Provenance and peer review Not commissioned; externally peer reviewed.

\section{REFERENCES}

1 Fangusaro J. Pediatric high-grade gliomas and diffuse intrinsic pontine gliomas. J Child Neurol 2009:24:1409-17.

2 Albright AL, Guthkelch AN, Packer RJ, et al. Prognostic factors in pediatric brain-stem gliomas. J Neurosurg 1986;65:751-5.

3 Cage TA, Samagh SP, Mueller S, et al. Feasibility, safety, and indications for surgical biopsy of intrinsic brainstem tumors in children. Childs Nerv Syst 2013;29:1313-19.

Copyright 2013 BMJ Publishing Group. All rights reserved. For permission to reuse any of this content visit

http://group.bmj.com/group/rights-licensing/permissions.

BMJ Case Report Fellows may re-use this article for personal use and teaching without any further permission.

Become a Fellow of BMJ Case Reports today and you can:

- Submit as many cases as you like

- Enjoy fast sympathetic peer review and rapid publication of accepted articles

- Access all the published articles

- Re-use any of the published material for personal use and teaching without further permission

For information on Institutional Fellowships contact consortiasales@bmjgroup.com

Visit casereports.bmj.com for more articles like this and to become a Fellow 